\title{
FORMULATION AND EVALUATION OF PRESS COATED TABLETS OF LANSOPRAZOLE
}

\author{
PRASANTHI D. , PRASHANTI S., MEGHANA G.
}

G. Pulla Reddy College of Pharmacy, Mehdipatnam, Hyderabad-28, Telangana, India

Email: prasanthidhanu@gmail.com

Received: 16 Feb 2019, Revised and Accepted: 11 Apr 2019

\begin{abstract}
Objective: Lansoprazole an proton pump inhibitor, degrades in acidic environment, hence protection of drug is done by coating the drug with enteric coating polymers. The aim and objective of the present study was to prepare enteric coated delayed release tablets of lansoprazole by using press coating technique.

Methods: Core tablets were prepared by direct compression and evaluated for their physico-chemical properties. Press coated tablets were formulated by using different combinations of ethyl cellulose, HPMC E15 and HPMC K4M as a coating layer. Core and coated tablets were optimized by dissolution studies. Fourier transform infra-red spectroscopy (FTIR) and differential scanning calorimetry (DSC) studies were performed to know the compatibility of drug with various excipients. Surface morphology and uniformity of coat was evaluated by Scanning electron microscopy (SEM). Stability of optimized formulation was evaluated according to ICH guidelines.
\end{abstract}

Results: Among the various formulations F5 containing ethyl cellulose: HPMC E15 (10:90) and F9 containing ethyl cellulose: HPMC K4M (25:75) were optimized based on the better drug release within $8 \mathrm{~h}$. DSC studies and FTIR studies revealed compatibility of drug with excipients. Obtained SEM photographs of tablets showed that the surface of core tablet is uniformly coated with coat by press coating. Stability studies showed that the formulations were stable.

Conclusion: As a result, delayed release press coated tablets developed in this study delivered lansoprazole in the intestine and protected the drug from degradation.

Keywords: Press coating technique, Lansoprazole, Enteric coated, Delayed release

(C) 2019 The Authors. Published by Innovare Academic Sciences Pvt Ltd. This is an open access article under the CC BY license (http://creativecommons.org/licenses/by/4.0/] DOI: http://dx.doi.org/10.22159/ijap.2019v11i4.32617

\section{INTRODUCTION}

Oral route is the most oldest and convenient route for the administration of therapeutic agents. The advantages of tablets includes dose precision, least content variability, low cost, flexibility of dosage, cheapest to package, provides chemical, mechanical and microbiologic stability and requires minimal storage space requirements [1]. The main disadvantages include GI irritability. To prevent GI irritation tablets are coated [2]. Tablet coating is a common pharmaceutical technique of applying a thin polymer based film to a tablet or granule containing active pharmaceutical ingredient (API) [3]. Enteric coating is of choice when the drug has to remain intact in the stomach, but dissolve and release the contents once it reaches the small intestine [4]. Their prime intention is to delay the release of drugs which are inactivated by the stomach contents or may cause nausea or bleeding by irritation of gastric mucosa [5]. The drug chosen was lansoprazole, which is a proton pump inhibitor it irreversibly inhibit the gastric $\mathrm{H}+-\mathrm{K}+$, ATPase proton pump which is the final common pathway for acid secretion in response to all varieties of stimuli. Its administration is associated with high healing rate for duodenal ulcer and peptic oesophagitis [6]. The benzimidazoles derivatives, however, are susceptible to degradation in acidic and neutral media and to prevent the degradation of the acid labile substances, they must be coated. Coating protects the drug from acid and also modifies the drug release pattern. There is a requirement for development of lansoprazole delayed release tablets to protect from acidic media by press coating technique. Press-coating, also referred to as double compression coating, compression coating, or dry coating, is an old technique first proposed by Noyes in 1896. An industrial application of this technique was introduced during the period 19501960 to allow the formulation of incompatible drugs [7]. Press coating technique does not require solvents, and achieves a greater increase in mass of core tablet than solvent-based methods [8]. It protects hygroscopic, light-sensitive, oxygen labile or acid-labile drugs. Additionally, compression coating has no limitation for the cores and hence overcomes the adhesion problem found in spraying methods [7]. Tablets with cylinder or special shapes can be press-coated. It is also possible to produce combination dosage forms, in which two active substances target different areas of the gastrointestinal tract [7]. Press coating allows the physical separation of incompatible drugs in the core and coat within the same dosage form [8]. Compression coated tablets consists of a core (fast disintegration or modified release) which is coated by compression with a solid barrier. This barrier should contain polymeric material, diluent(as a release modifier) and drug (for extended release) [7]. Compression coated tablets could be modulated to provide different release patterns depending on the drug distribution and with different type of controlling polymer used in core and coat. Based on this concept, the possibly obtainable modified drug releases are extended release or delayed release [8]. For the time controlled release system from compression coated tablets, the amount of the outer shell is a key factor for controlling the lag time [9]. Higher amount of outer coating added would prolong the lag time of drug release. Insufficient amount of polymer coat would result in absence of the lag time, since the drug might be released through the incomplete form of compression coat. The main difficulty in the manufacture of press-coated tablets is how to center the inner core tablet under rapid processing conditions. Eccentric localization may alter lag time and release profile, leading to the changes in drug bioavailability [10]. Reproducibility of drug release from press-coated tablets becomes uncertain with off center placement of the core tablet. Recently, the novel ENCORE ${ }^{\mathrm{TM}}$, one-step dry-coated tablet (OSDRC) method, pulse-echo ultrasonic approach, and x-ray computed tomography (CT) technique has been applied to solve manufacturing problems with central position deviation and absence of a core in the press-coated tablet [9]. In the present study, enteric coating polymers were used for press coating technique. Polymers used for coating are different combinations of ethyl cellulose with HPMC E15 and HPMC K4M. The amount of coating on surface of tablet is critical to the effectiveness of oral dosage form.

\section{MATERIALS AND METHODS}

Lansoprazole was obtained as gift sample from Dr. Reddy's Laboratories Pvt Ltd, HPMC E15, HPMC K4M, Micro crystalline cellulose, Ethyl cellulose E 1415 were procured from Yarrow chemical products, Mumbai. Polyvinylpyrrolidone, Sodium starch glycolate were procured from SD fine chemicals limited, Mumbai. 


\section{Preparation of core tablet}

The inner core tablets were prepared by using direct compression method. Powder mixtures of Lansoprazole, micro crystalline cellulose (MCC), poly vinyl pyrrolidine (PVP), sodium starch glycolate (SSG) were dry blended for 20 min followed by addition of magnesium stearate. These mixtures were then further blended for $10 \mathrm{~min} .50 \mathrm{mg}$ of resultant powder blend was compressed using 4.76 $\mathrm{mm}$ punch to obtain core tablet [11]. Different formulations of core tablet are mentioned in table 1.

Table 1: Formulations of core tablet

\begin{tabular}{lllllll}
\hline Ingredients & CT1 & CT2 & CT3 & CT4 & CT5 & CT6 \\
\hline Drug & $30 \mathrm{mg}$ & $30 \mathrm{mg}$ & $30 \mathrm{mg}$ & $30 \mathrm{mg}$ & $30 \mathrm{mg}$ \\
MCC & $17.5 \mathrm{mg}$ & $17 \mathrm{mg}$ & $16.5 \mathrm{mg}$ & $16 \mathrm{mg}$ & $15.5 \mathrm{mg}$ \\
PVP & $1.5 \mathrm{mg}$ & $1.5 \mathrm{mg}$ & $1.5 \mathrm{mg}$ & $1.5 \mathrm{mg}$ & $1.5 \mathrm{mg}$ \\
SSG & $0.75 \mathrm{mg}$ & $1.25 \mathrm{mg}$ & $1.75 \mathrm{mg}$ & $2.25 \mathrm{mg}$ & $2.75 \mathrm{mg}$ \\
Mg stearate & $0.25 \mathrm{mg}$ & $0.25 \mathrm{mg}$ & $0.25 \mathrm{mg}$ & $0.25 \mathrm{mg}$ & $-1.5 \mathrm{mg}$ & $0.25 \mathrm{mg}$ \\
\hline
\end{tabular}

\section{Preparation of press coated tablet}

The various formulation compositions containing ethyl cellulose and HPMC E15 and other formulation compositions containing ethyl cellulose and HPMC K4M were weighed and dry blended at about 10 min. These are used as coating material to prepare press coated tablets respectively by direct compression. The optimized core tablets are press coated with $100 \mathrm{mg}$ of mixed blend. $75 \mathrm{mg}$ of coating layer material was weighed and transferred into $6 \mathrm{~mm}$ die and then core tablet was carefully placed manually at the center. The remaining $25 \mathrm{mg}$ of barrier material was added into die and compressed [11]. Different coating combinations of core tablets are mentioned in table 2 .

Table 2: Different coating combinations of core tablet

\begin{tabular}{|c|c|c|c|c|c|c|c|c|c|c|c|c|c|}
\hline COAT(mg) & F1 & F2 & F3 & F4 & F5 & F6 & F7 & F8 & F9 & F10 & F11 & F12 & F13 \\
\hline Ethyl cellulose & 100 & 75 & 50 & 25 & 10 & 5 & - & - & 25 & 50 & 75 & 90 & 95 \\
\hline HPMC E15 & - & 25 & 50 & 75 & 90 & 95 & 100 & - & - & - & - & - & - \\
\hline HPMC K4M & - & - & - & - & - & - & - & 100 & 75 & 50 & 25 & 10 & 5 \\
\hline
\end{tabular}

Total weight of tablet-150 mg

\section{Evaluation of core tablet and coated tablet}

\section{Pre compression parameters}

The powder blend for core and coated tablets was evaluated for flow properties and compressibility.

\section{Bulk density}

Bulk density was determined by pouring $15 \mathrm{gm}$ (M) of sample through a glass funnel into $50 \mathrm{ml}$ graduated cylinder. The bulk volume (V) occupied by the samples were recorded [12]. Bulk density was calculated as:

$$
\text { bulk density }=\frac{\text { mass }(\mathrm{M})}{\text { Bulk volume (V) }}
$$

\section{Tapped density}

Tapped density was determined by using Electro lab density tester, which consists of a graduated cylinder mounted on a mechanical tapping device. An accurately weighed (M) sample of powder was carefully added to the cylinder with the aid of a funnel [12]. Typically, the initial volume was noted, and the sample is then tapped (100 tappings) until no further reduction in volume is noted or the percentage of difference is not more than $2 \%$. A sufficient number of taps should be employed to assure reproducibility for the material in question. True volume (V) was noted and tapped density is calculated using following formula:

$$
\text { Tapped density }=\frac{\operatorname{mass}(\mathrm{M})}{\text { True volume }(\mathrm{V})}
$$

\section{Compressibility index and hausner ratio}

Both the compressibility index and the Hausner's ratio were determined by using bulk density and the tapped density of a powder [12].

$$
\begin{gathered}
\text { compressibility index }=\frac{\text { Tapped density }- \text { Bulk density }}{\text { Tapped density }} \times 100 \\
\text { Hausner ratio }=\frac{\text { tapped density }}{\text { bulk density }}
\end{gathered}
$$

\section{Angle of repose}

The angle of repose has been used to characterize the flow properties of solids. Angle of repose is a characteristic related to interparticulate friction or resistance to movement between particles [13]. This is the maximum angle possible between surface of pile of powder or granules and the horizontal plane. A funnel was fixed at a height approximately of $2 \mathrm{~cm}$ over the platform. The loose powder was slowly passed along the wall of funnel, till the cone of the powder formed. Determine the angle of repose by measuring the height of the cone of powder and radius of the heap of powder.

$$
\operatorname{Tan} \theta=\frac{\mathrm{h}}{\mathrm{r}}
$$

Where, $\theta=$ angle of repose, $h=$ height, $r=$ radius.

\section{Post compression parameters of core and coated tablets}

The prepared tablets were evaluated for various parameters.

\section{Weight variation}

Twenty tablets were randomly selected and average weight was determined. Then individual tablets were weighed and percent deviation from the average was calculated.

\section{Thickness}

The thickness in millimeters ( $\mathrm{mm}$ ) was measured individually for 10 pre weighed tablets by using screw gauge. The average thickness and standard deviation were reported.

\section{Hardness}

It was measured using a tablet hardness tester (Monsanto hardness tester). Three tablets from each formulation batch were tested randomly and the average reading noted [14]

\section{Friability}

Friability of the tablets was determined using Roche Friabilator (Electrolab, India). This device consists of a plastic chamber that is set to revolve around $25 \mathrm{rpm}$ for 4 min dropping the tablets at a distance of 6 inches with each revolution. Pre weighed sample $\left(\mathrm{W}_{0}\right)$ 
of 20 tablets was placed in the friabilator and were subjected to 100 revolutions. Tablets were dusted using a soft muslin cloth and reweighed (W) [14]. The friability (F \%) is given by the formula.

$$
\text { Friability }(\% \mathrm{~F})=\frac{1-\mathrm{W} 0}{\mathrm{~W}} \times 100
$$

Where, $\mathrm{W}_{0}$ is weight of the tablets before the test and $\mathrm{W}$ is the weight of the tablets after test

\section{Disintegration time}

Disintegration time was measured using a disintegration apparatus. Randomly six tablets were selected from each batch for disintegration test. Disintegration test was performed in $900 \mathrm{ml} 6.8$ $\mathrm{pH}$ phosphate buffer with SLS $(0.3 \%)$ at $37 \pm 0.5^{\circ} \mathrm{C}$ temperature and at the rate of $30 \pm 2$ cycles/min.

\section{Assay}

Twenty tablets were randomly selected and average weight was calculated. Tablets were powdered in a glass mortar. Powder equivalent to $5 \mathrm{mg}$ was weighed and dissolved in $100 \mathrm{ml}$ of $6.8 \mathrm{pH}$ phosphate buffer with SLS (0.3\%) in volumetric flask. This dispersion was filtered and $1.2 \mathrm{ml}$ of the above solutions were taken and diluted to $10 \mathrm{ml}$ with distilled water. The absorbance of this solution was determined at $286 \mathrm{~nm}$ against the blank. The percentage assay was calculated from the standard curve.

\section{Dissolution study}

The release rate of lansoprazole was determined using USP dissolution testing apparatus-2 (paddle method). The dissolution medium was $0.1 \mathrm{~N} \mathrm{HCl}$ and $6.8 \mathrm{pH}$ phosphate buffer with SLS $(0.3 \%)$. For core tablets $900 \mathrm{ml}$ of $6.8 \mathrm{pH}$ phosphate buffer with SLS $(0.3 \%)$ was used as dissolution media. For coated tablets, $500 \mathrm{ml}$ of dissolution medium of $0.1 \mathrm{~N} \mathrm{HCl}$ was taken in dissolution apparatus for $120 \mathrm{~min}$. Then $25 \mathrm{ml}$ was withdrawn and leaving the remaining $475 \mathrm{ml}$ for the use in the buffer stage. Add $425 \mathrm{ml}$ of $6.8 \mathrm{pH}$ phosphate buffer with SLS (0.3\%) into each bowl containing $475 \mathrm{ml}$ of $0.1 \mathrm{~N}$ hydrochloric acid sample solution. Adjust PH 6.8 by using dilute orthophosphoric acid or dilute sodium hydroxide. The dissolution was performed at $37 \pm 0.5{ }^{\circ} \mathrm{C}$ temperature with $75 \mathrm{rpm}$. A sample $(5 \mathrm{ml})$ of the solution was withdrawn from the dissolution apparatus hourly and the samples were replaced with fresh dissolution medium [15]. The samples were filtered and absorbance of these solutions was measured at about $306 \mathrm{~nm}$, using acid stage media as blank and at $286 \mathrm{~nm}$ using buffer as blank using a UV spectrophotometer. The percentage drug release was plotted against time to determine the release profile.

\section{Analysis of drug release kinetics}

To analyze the in vitro release data various kinetic models were used to describe the release kinetics [14]. The zero order rate Eq. (1); first order Eq. (2); Higuchi Eq. (3); Korsmeyer Peppas Eq. (4).

$$
\mathrm{C}=\mathrm{K}_{0} \mathrm{t} \text {--------Eq. (1) }
$$

$$
\begin{gathered}
\log \mathrm{C}=\log _{0-} \mathrm{K}_{1} \mathrm{t} / 2.303------- \text { Eq. (2) } \\
\mathrm{Q}=\mathrm{K}_{\mathrm{H}} \mathrm{t}^{1 / 2}{ }^{1 / 2} \text {-----Eq. (3) } \\
\mathrm{M}_{\mathrm{t}} / \mathrm{M}_{\infty}=\mathrm{Kt}^{\mathrm{n}} \text {--------Eq. (4) }
\end{gathered}
$$

Where, $\mathrm{C}$ is the concentration of drug at time $t, \mathrm{~K}_{0}$ is zero-order rate constant, $t$ is time, $C_{0}$ is the initial concentration of drug, $K_{1}$ is first order constant, $\mathrm{Q}$ is the amount of drug at time $\mathrm{t}, \mathrm{K}_{\mathrm{H}}$ is the constant reflecting the design variables of the system, $\mathrm{M}_{t} / \mathrm{M}_{\infty}$ is fraction of drug released at time $\mathrm{t}, \mathrm{K}$ is the release rate constant incorporating structural and geometric characteristics of the tablet, and $\mathrm{n}$ is the release exponent. The $\mathrm{n}$ value is used to characterize different release mechanisms.

\section{Drug-excipient compatibility}

Lansoprazole compatibility with excipients was studied by FTIR and DSC. The IR spectroscopy was obtained by a FTIR spectrophotometer (Shimadzu, Japan) using KBR pellets [16]. DSC analysis was performed using Q-1000 TA Instruments Perkin-Elmer pyris differential scanning calorimeter (DSC). The instrument was calibrated with indium standard. 3-5 mg samples were weighed and placed in a closed, hermetic sample pans with pin hole. Thermograms were obtained by heating the sample at a constant rate $10{ }^{\circ} \mathrm{C} / \mathrm{min}$. A dry purge of nitrogen gas $(50 \mathrm{ml} / \mathrm{min})$ was used for all runs. Samples were heated from $0{ }^{\circ} \mathrm{C}$ to $210.0^{\circ} \mathrm{C}$. The melting point, heat of fusion, appearance of any new peak and peak shape were noted [16].

\section{Surface morphology}

Surface Morphology and cross-sectional view of coated tablets were evaluated by SEM. The surface should be uniform and the core tablet should be completely surrounded by the coat.

\section{Stability}

The stability studies of prepared formulations were carried out at accelerated stability condition $\left(40^{\circ} \mathrm{C} \pm 2{ }^{\circ} \mathrm{C} / 75 \% \pm 5 \% \mathrm{RH}\right)$ as per ICH guidelines over a period of 3 mo. The changes in their physical appearance, average weight of tablets, hardness, release profile and the drug content were observed.

\section{RESULTS AND DISCUSSION}

Lansoprazole core tablets were prepared according to formulations CT1-CT6. The amount of SSG is gradually increased from 1.5\%-5.5\% of tablet weight in CT1 to CT5, where as in CT6, SSG is not used. In the core tablet formulation PVP is added which is used as binder, magnesium stearate is used as lubricant and MCC is used as diluent. This powder mixture was dry blended and compressed in $4.76 \mathrm{~mm}$ punch to form $50 \mathrm{mg}$ tablet. These formed tablets were further evaluated.

\begin{tabular}{|c|c|c|c|c|c|}
\hline Formulation & Bulk density (gm/cc) & Tapped density (gm/cc) & Compressibility index (\%) & Hausner's ratio & Angle of repose \\
\hline Drug & $0.40 \pm 0.23$ & $0.58 \pm 0.32$ & $31.03 \pm 0.24$ & $1.43 \pm 0.1$ & $39^{\circ} \pm 0.29$ \\
\hline CT1 & $0.581 \pm 0.097$ & $0.646 \pm 0.078$ & $9.63 \pm 0.14$ & $1.10 \pm 0.1$ & $23^{\circ} \pm 0.17$ \\
\hline CT2 & $0.584 \pm 0.103$ & $0.649 \pm 0.063$ & $10.02 \pm 0.23$ & $1.11 \pm 0.2$ & $23^{\circ} \pm 0.30$ \\
\hline CT3 & $0.583 \pm 0.057$ & $0.646 \pm 0.101$ & $9.69 \pm 0.19$ & $1.10 \pm 0.1$ & $23^{\circ} \pm 0.24$ \\
\hline CT4 & $0.563 \pm 0.068$ & $0.646 \pm 0.073$ & $12.84 \pm 0.28$ & $1.14 \pm 0.1$ & $22^{\circ} \pm 0.11$ \\
\hline CT5 & $0.560 \pm 0.095$ & $0.642 \pm 0.059$ & $13.24 \pm 0.35$ & $1.15 \pm 0.2$ & $22^{\circ} \pm 0.32$ \\
\hline CT6 & $0.589 \pm 0.104$ & $0.648 \pm 0.092$ & $9.1 \pm 0.16$ & $1.10 \pm 0.1$ & $23^{\circ} \pm 0.29$ \\
\hline
\end{tabular}

The physical properties like bulk density, tapped density, compressibility index, Hausner's ratio and angle of repose for lansoprazole and formulations CT1 to CT6 blend are shown in table 3.

Table 3: Pre compression parameters of core tablets

Values are expressed as mean $\pm \mathrm{SD}, \mathrm{n}=3$

From table 3 it is seen that lansoprazole has poor flow property. But when mixed with excipients the flow property is excellent. From CT1CT3 and CT6 the flow property is excellent, because MCC increases the flow property. For CT4 and CT5 the flow property is good (from Hausner's ratio inference), because when compared to CT1-CT3 and CT6, MCC amount is reduced. So, there is slight decrease in flow 
property of mixture. As the angle of repose which indicates flowability and compressibility index which indicates compressibility is good, direct compression is used for formulation of tablets.
The compressed tablets are evaluated for physico-chemical parameters such as hardness, thickness, friability, weight variation, assay and disintegration test. These are given in table 4 .

Table 4: Post compression parameters of core tablet

\begin{tabular}{|c|c|c|c|c|c|c|}
\hline Formulation code & $\begin{array}{l}\text { Thickness } \\
\text { (mm) }\end{array}$ & $\begin{array}{l}\text { Hardness } \\
\left(\mathrm{kg} / \mathrm{cm}^{2}\right)\end{array}$ & $\begin{array}{l}\text { Friability } \\
\text { (\%) }\end{array}$ & Weight variation (\%) & Assay (\%) & Disintegration time (min) \\
\hline CT1 & $2.14 \pm 0.45$ & $2.5 \pm 0.25$ & $0.82 \pm 0.04$ & $4.923 \pm 0.05$ & $99.58 \pm 1.65$ & $3.6 \pm 0.35$ \\
\hline СТ2 & $2.23 \pm 0.01$ & $2.7 \pm 0.02$ & $0.86 \pm 0.06$ & $3.912 \pm 0.05$ & $99.67 \pm 0.08$ & $2.0 \pm 0.28$ \\
\hline CT3 & $2.29 \pm 0.03$ & $2.2 \pm 0.02$ & $0.69 \pm 0.02$ & $4.04 \pm 0.07$ & $100.1 \pm 0.38$ & $1.1 \pm 0.24$ \\
\hline CT4 & $2.32 \pm 0.04$ & $2.4 \pm 0.04$ & $0.67 \pm 0.07$ & $3.98 \pm 0.06$ & $99.56 \pm 0.11$ & $0.45 \pm 0.17$ \\
\hline CT5 & $2.53 \pm 0.05$ & $3.0 \pm 0.01$ & $0.71 \pm 0.01$ & $3.87 \pm 0.05$ & $99.78 \pm 0.15$ & $0.30 \pm 0.25$ \\
\hline CT6 & $2.26 \pm 0.04$ & $2.7 \pm 0.02$ & $0.76 \pm 0.04$ & $3.92 \pm 0.02$ & $100.78 \pm 0.87$ & $6.1 \pm 0.23$ \\
\hline
\end{tabular}

Values are expressed as mean $\pm S D, n=3$.

The hardness test is one of the control parameter during the manufacturing of tablets. The recommended hardness for core tablet is $2-3 \mathrm{~kg} / \mathrm{cm}^{2}$. The hardness of core tablets from CT1-CT6 is found to be within limits. The thickness of tablets is related to tablet hardness. The thickness of all core tablets is found to be within limits. The average weight variation of tablets was found within limits of 5\% (according to Indian Pharmacoepia). The average weight variation of core tablets CT1-CT6 was within 3-4\% range which indicates that they are within limits. The friability value which is also affected by the hardness value of tablets should be in the range of $0.5-1 \%$ limits [17]. It was found that the friability of prepared core tablets is within standards. The assay of all core tablets was found to be within limits. The disintegration test is performed for all core tablets. From CT1-CT5 the amount of SSG is increased. The disintegration time is decreased based on amount of SSG. So, for CT5 the disintegration time is faster when compared to all other formulations i. e, CT1-CT4. In CT6 formulation SSG is not used, so, it took longer time to disintegrate when compared to all other formulations.

Dissolution study of the core tablets was performed in $6.8 \mathrm{pH}$ phosphate buffer with $0.3 \%$ SLS. Formulations containing SSG (CT1 to CT5) released within $15 \mathrm{~min}$, except CT6 which does not contain super disintegrant, released in $20 \mathrm{~min}$. From fig. 1, we can observe that with increase in the SSG concentration the dissolution time is decreased. The core tablet CT2 which consists of optimum amount of SSG $(2.5 \%$ i.e., $1.25 \mathrm{mg}$ ) is used to develop press coated tablets. As the objective is to overcome the acid instability and then immediate release of drug.

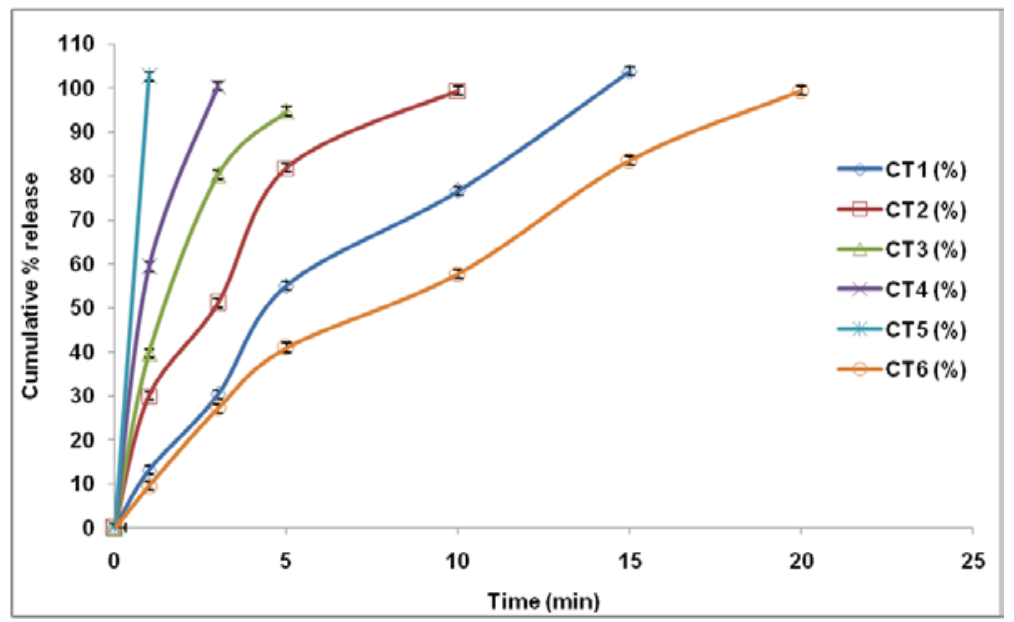

Fig. 1: Dissolution profile of core tablet (values are expressed as mean $\pm S D, n=3$ )

To the core tablet CT2, different polymers (ethyl cellulose, HPMC E15 and HPMC K4M) were added according to table 2 and compressed into a tablet. The prepared press coated tablets were further evaluated for hardness, thickness, friability, weight variation and assay. The recommended hardness for tablet is $4-8 \mathrm{~kg} / \mathrm{cm}^{2}$. From formulations F1-F13 the hardness was found to be within range $4-5 \mathrm{~kg} / \mathrm{cm}^{2}$ which indicate that the hardness is within limits. The thickness of tablets is related to tablet hardness. The thickness of all tablets is found to be within limits. The average weight variation of tablets was found to be within range $2-4 \%$ which indicates that it is within limits. It was found that the friability of prepared tablets was within the range $0.6-0.8 \%$. The assay of prepared tablets was also found within the limits with range $97-99 \%$.

Press-coated tablets were evaluated for drug release in 0.1NHCL and $6.8 \mathrm{pH}$ phosphate buffer with $0.3 \%$ SLS. From fig. 2 , it is observed as ethyl cellulose is decreased gradually from F1-F6 drug release is increased and from F7-F13 (fig. 3) as ethyl cellulose is increased gradually drug release is decreased.

Varying concentrations of ethyl cellulose incorporated controlled the drug release. This may be attributed due to decreased penetration of the solvent molecules in the presence of the hydrophobic polymer, leading to reduced diffusion of the drug from the matrix. Leuenberger et al. reported that, according to penetration theory, when a matrix is composed of a water-insoluble polymer, drug release occurs by dissolution of the active ingredients through capillaries composed of interconnecting drug particle clusters and the pore [18]. As drug release continues, the interconnecting clusters increase the pore network through which interior drug clusters can diffuse with more ethyl cellulose particles present, and the theory predicts that fewer clusters of soluble drug 
substance are formed. Furthermore, the presence of finite drug clusters is more statistically possible. The resulting pore network becomes less extensive and more tortuous resulting in slower drug release. R. Enayatifard reported that, although incorporation of EC controlled drug release to some extent, the combination of this polymer with HPMC increased the release of the drug i.e. $94 \%$ in $8 \mathrm{~h}$ in diltiazem tablet formulation. The reason might be that its large hydrophobic molecules imposed a discontinuity in the gel-structure leading to formation of a weaker barrier than the HPMC gel alone [14]. Pham AT et al. and Skoug et al. reported that the extent of polymer swelling and the hydration of the microstructure formed within the gel layer also vary with the degree of polymer interaction with hydrating media $[19,20]$. Gangane P. S. et al. reported captopril release from press coated tablets depends on ratio of EC/HPMCK4M used [21]. Formulation F5 (10 mg EC, $90 \mathrm{mg}$ HPMC E15) and F9 (25 mg EC,75 mg HPMC K4M) were optimized based on limit given in United states pharmacopoeia (USP) i.e., USP limit-NMT 10\% drug release in $0.1 \mathrm{~N} \mathrm{HCl}$ and NLT $75 \%$ in $6.8 \mathrm{pH}$ buffer.

The data obtained from dissolution studies of the entire formulations F1-F13 were fitted to various kinetic equations such as zero order, first order, Higuchi's model, Korsemeyer peppas. The results are shown in table 5 .

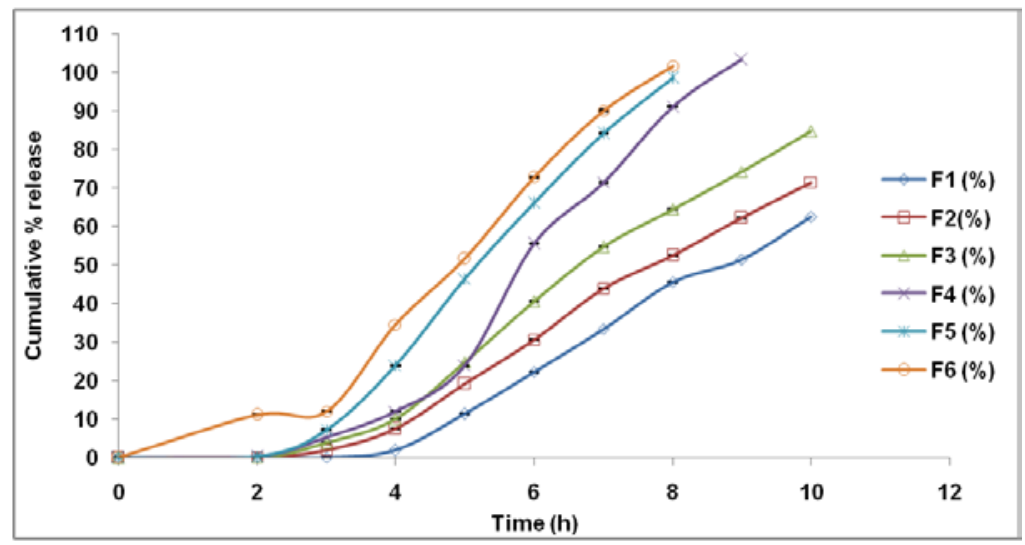

Fig. 2: Dissolution profile of F1-F6 (values are expressed as mean $\pm S D, n=3$ )

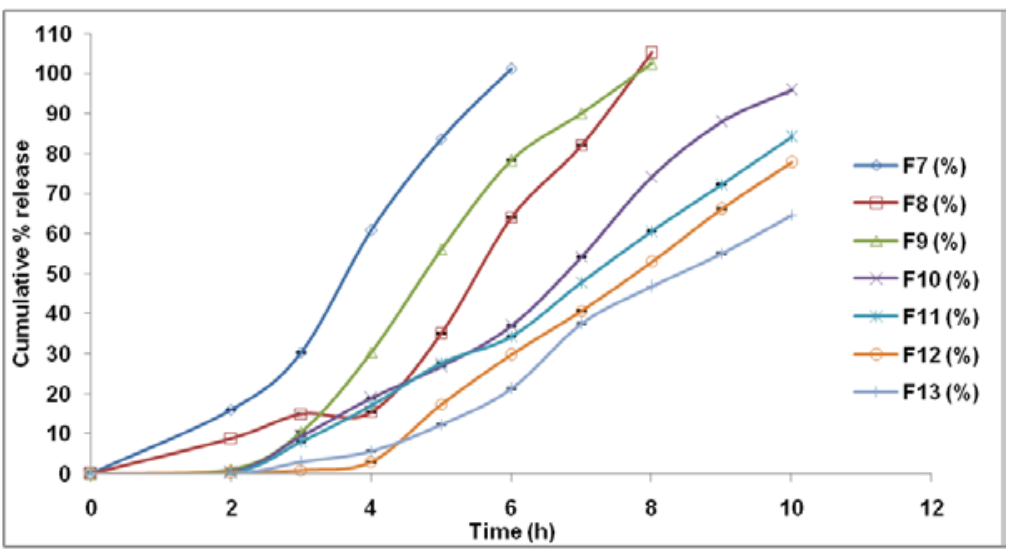

Fig. 3: Dissolution profile of F7-F13 (values are expressed as mean $\pm S D, n=3$ )

Table 5: Drug release kinetics

\begin{tabular}{|c|c|c|c|c|c|c|}
\hline \multirow[t]{2}{*}{ Formulation code } & \multirow{2}{*}{$\begin{array}{l}\text { Zero order } \\
\mathbf{R}^{2}\end{array}$} & \multirow{2}{*}{$\begin{array}{l}\text { First order } \\
\mathbf{R}^{2}\end{array}$} & \multirow{2}{*}{$\begin{array}{l}\text { Higuchi } \\
\mathbf{R}^{2}\end{array}$} & \multicolumn{2}{|c|}{ Korsemeyer-peppas } & \multirow[t]{2}{*}{ Release mechanism } \\
\hline & & & & $\mathbf{R}^{2}$ & n & \\
\hline F1 & 1 & 0.818 & 0.648 & 0.945 & 1.385 & Super case 2 \\
\hline F2 & 0.927 & 0.791 & 0.703 & 0.778 & 1.759 & Super case 2 \\
\hline F3 & 0.939 & 0.771 & 0.711 & 0.689 & 1.430 & Super case 2 \\
\hline $\mathrm{F} 4$ & 0.89 & 0.965 & 0.969 & 0.650 & 1.770 & Super case 2 \\
\hline F5 & 0.913 & 0.939 & 0.679 & 0.973 & 2.429 & Super case 2 \\
\hline F6 & 0.913 & 0.884 & 0.681 & 0.932 & 2.617 & Super case 2 \\
\hline F7 & 0.949 & 0.896 & 0.762 & 0.950 & 2.367 & Super case 2 \\
\hline F8 & 0.906 & 0.958 & 0.675 & 0.994 & 2.075 & Super case 2 \\
\hline F9 & 0.926 & 0.877 & 0.711 & 0.929 & 2.597 & Super case 2 \\
\hline F10 & 0.936 & 0.901 & 0.723 & 0.968 & 2.183 & Super case 2 \\
\hline F11 & 0.94 & 0.798 & 0.725 & 0.816 & 2.521 & Super case 2 \\
\hline F12 & 0.900 & 0.813 & 0.662 & 0.751 & 2.650 & Super case 2 \\
\hline F13 & 0.900 & 0.753 & 0.665 & 0.742 & 2.583 & Super case 2 \\
\hline
\end{tabular}

From table 5, it was observed that the "n" value of 2.429 obtained for F5 formulation, the drug release was found to follow super case 2 transport. This value indicates erosion mechanism. Also, the drug release mechanism was best explained by first order equation, as the plots showed the highest linearity $\left(r^{2}=0.939\right)$, followed by korsemeyer peppas equation $\left(r^{2}=0.973\right)$. As the drug release was best fitted in first 
order kinetics, it indicated that the rate of drug release is concentration dependent. For optimized formulation F9, "n" value was found to be 2.367. The drug release was found to follow super case 2 transport. This value indicates erosion mechanism. Also, the drug release mechanism was best explained by zero order equation, as the plots showed the highest linearity $\left(r^{2}=0.926\right)$, followed by korsemeyer peppas equation $\left(r^{2}=0.929\right)$. As the drug release was best fitted in zero order kinetics, it indicated that the rate of drug release is concentration independent.
The optimized formulations were further studied for drug excipient compatibility, surface morphology and stability.

From fig. 4 FTIR studies it was observed that the characteristic peaks at $1170(\mathrm{C}-\mathrm{O}-\mathrm{C}$ bending), $3200(\mathrm{~N}-\mathrm{H}$ stretching), 1268 (C=N stretching), $\quad 1600(\mathrm{C}=0$ stretching), 2988, 2940, $2884 \quad$ (C-H stretching) are present in both the pure drug and formulation, indicating no chemical interaction between drug and excipients.
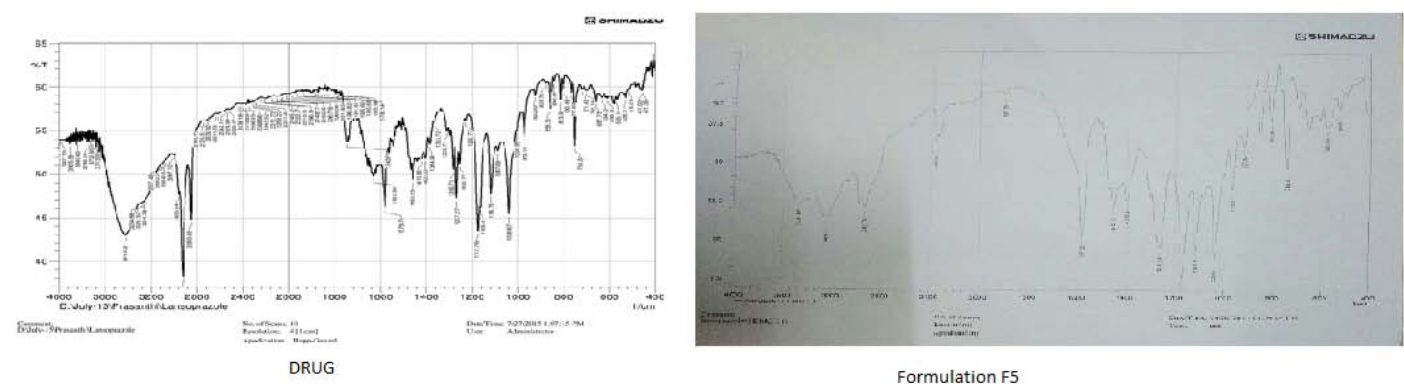

Formulation F5

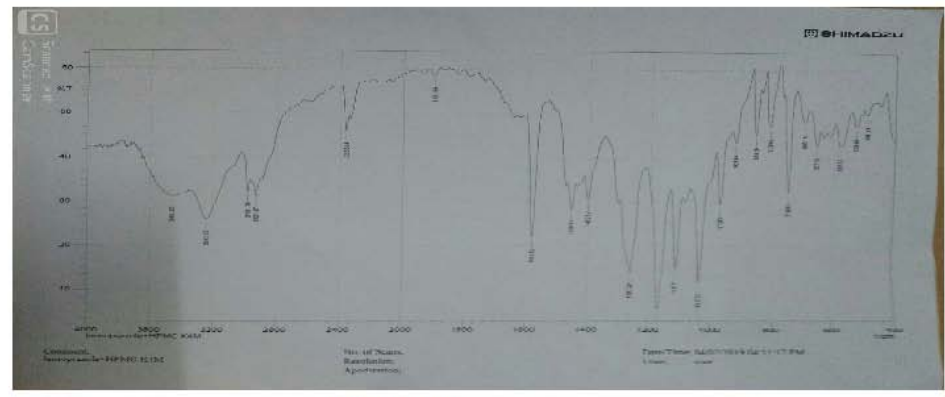

Formulation F9

Fig. 4: FTIR peaks of drug, formulation F5 and formulation F9

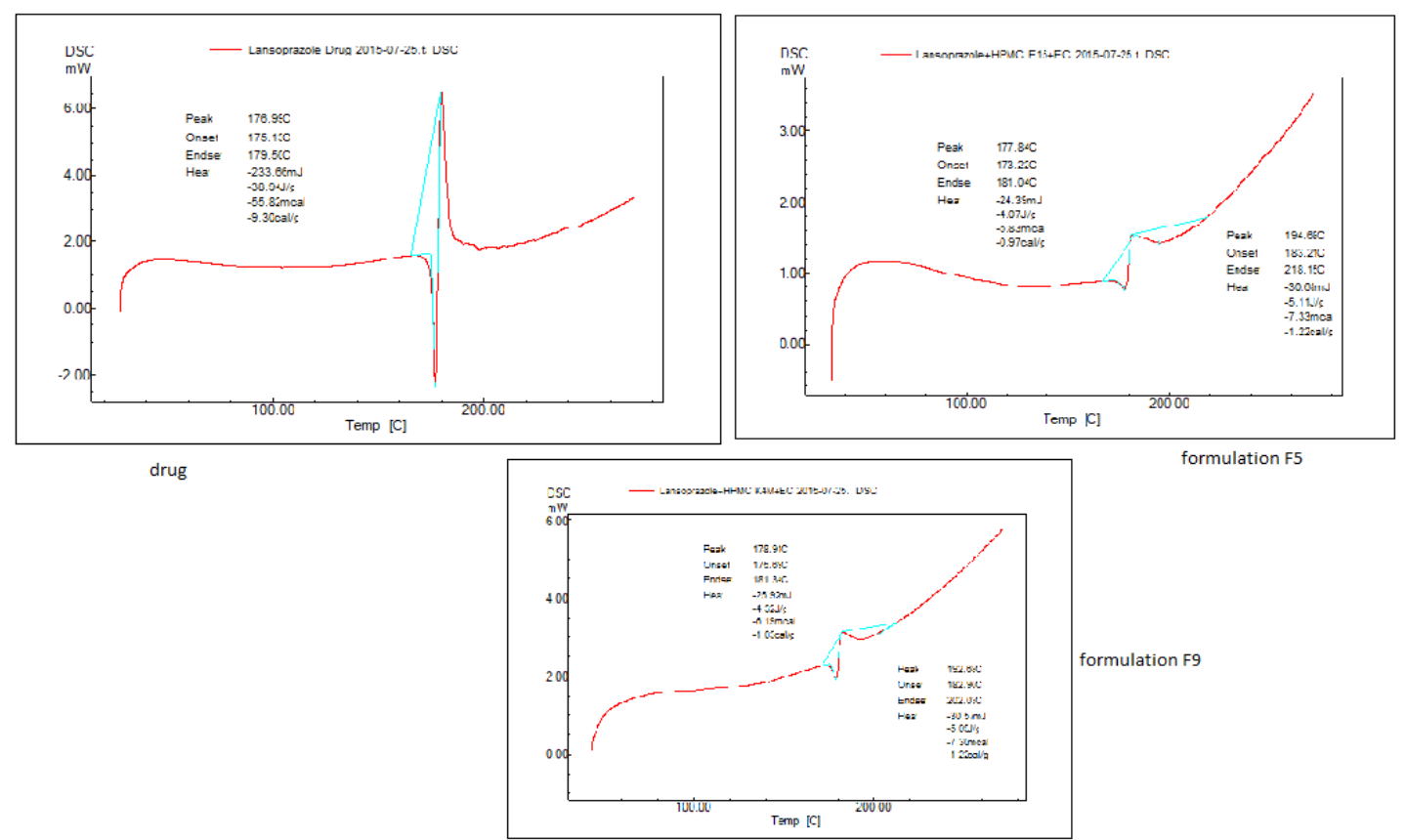

Fig. 5: DSC peaks of drug, formulation F5 and formulation F9

Thermal behavior of pure lansoprazole, formulation F5 and F9 physical mixture are depicted in fig. 5. The pure lansoprazole showed melting endothermic peak at $176.99{ }^{\circ} \mathrm{C}$, in formulation $\mathrm{F} 5$ peak $177.84{ }^{\circ} \mathrm{C}$ and formulation $\mathrm{F} 9$ peak at $178.91{ }^{\circ} \mathrm{C}$. These minor changes may not necessarily indicate potential incompatibility.
The effect of coating on the morphology of the core tablet was observed using SEM. The main objective of scanning electron microscopy is to study the different coating layers on core tablet. Obtained SEM photographs of tablets coated with ethyl cellulose and HPMC E15 i.e. F5 and tablets coated with ethyl cellulose and HPMC 


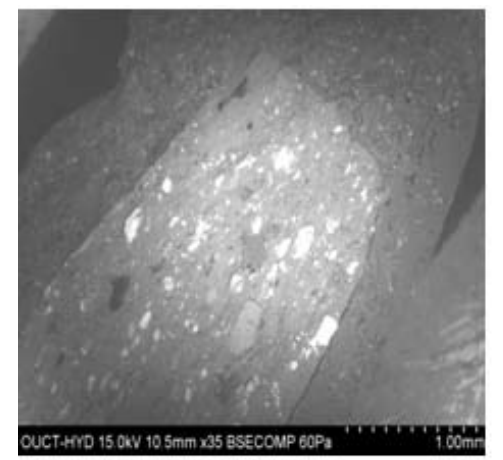

formulation F5

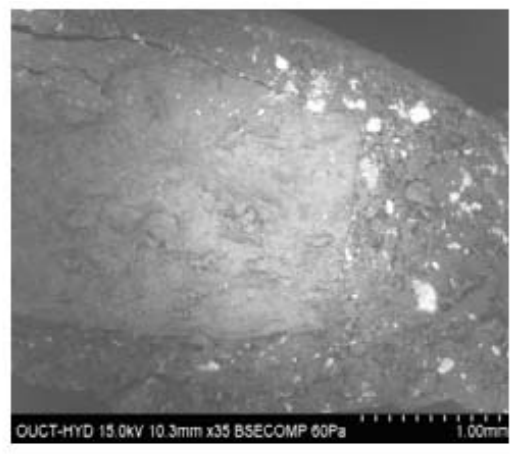

formulation F9

Fig. 6: SEM of formulation F5 and F9

Stability of a drug in a dosage form at different environmental conditions is important as it determines the expiry date of that particular formulation. Among the 13 formulations optimized formulations F5 and F9 were selected for stability studies. The stability studies of optimized formulation F5 and F9 (table 6) was carried out at $40{ }^{\circ} \mathrm{C} \pm 2{ }^{\circ} \mathrm{C} / 75 \% \pm 5 \% \mathrm{RH}$ as per ICH guidelines over a period of 3 mo. There is no significant change in their physical appearance, average weight of tablets and hardness. The release profile and the drug content also did not show any significant changes indicating that there were no changes in the physical as well as chemical characteristics of the formulation [22]. Hence, it can be concluded from the results that the developed tablets were stable and retain their pharmaceutical properties over a period of 3 mo.

Table 6: Stability studies of formulation F5 andF9

\begin{tabular}{|c|c|c|c|c|c|c|c|c|}
\hline \multirow[t]{2}{*}{ Parameters } & \multicolumn{4}{|c|}{ formulation F5 } & \multicolumn{4}{|c|}{ formulation F9 } \\
\hline & Initial & $1^{\text {st }}$ month & $2^{\text {nd }}$ month & $3^{\text {rd }}$ month & Initial & $1^{\text {st }}$ month & $2^{\text {nd }}$ month & $3^{\text {rd }}$ month \\
\hline Physical appearance & white & white & white & white & white & white & white & white \\
\hline Weight variation (\%) & $4.06 \pm 0.07$ & $4.06 \pm 0.07$ & $4.06 \pm 0.07$ & $4.06 \pm 0.07$ & $3.91 \pm 0.05$ & $3.91 \pm 0.05$ & $4.02 \pm 0.09$ & $4.08 \pm 0.07$ \\
\hline Hardness $\left(\mathrm{kg} / \mathrm{cm}^{2}\right)$ & $4.7 \pm 0.02$ & $4.7 \pm 0.02$ & $4.7 \pm 0.02$ & $4.7 \pm 0.02$ & $4.5 \pm 0.02$ & $4.5 \pm 0.02$ & $4.5 \pm 0.02$ & $4.5 \pm 0.02$ \\
\hline Drug content $(\%)$ & $98.14 \pm 0.22$ & $98.14 \pm 0.22$ & $97.32 \pm 0.22$ & $97.21 \pm 0.22$ & $97.8 \pm 0.51$ & $97.8 \pm 0.51$ & $97.8 \pm 0.87$ & $97.21 \pm 0.23$ \\
\hline Friability (\%) & $0.86 \pm 0.06$ & $0.86 \pm 0.06$ & $0.86 \pm 0.06$ & $0.86 \pm 0.06$ & $0.69 \pm 0.02$ & $0.69 \pm 0.02$ & $0.69 \pm 0.02$ & $0.69 \pm 0.02$ \\
\hline Invitro release (\%) in $8 \mathrm{Hrs}$ & $98.53 \pm 0.05$ & $98.53 \pm 0.07$ & $96.38 \pm 0.04$ & $96.11 \pm 0.06$ & $102.33 \pm 0.11$ & $102.33 \pm 0.03$ & $101.99 \pm 0.14$ & $101.84 \pm 0.12$ \\
\hline
\end{tabular}

Values are expressed as mean $\pm \mathrm{SD}, \mathrm{n}=3$.

\section{CONCLUSION}

Lansoprazole is an acid liable drug which degrades at acidic $\mathrm{pH}$ of stomach. In order to delay the release in the stomach and promote the drug release in the intestine, enteric coating of the drug was attempted. An enteric coated delayed release formulation was successfully formulated by press coating technique. Among the various formulations F5 containing ethyl cellulose: HPMC E15 (10:90) and F9 containing ethyl cellulose: HPMC K4M (25:75) were optimized based on the better drug release within $8 \mathrm{~h}$, according to USP limitNMT $10 \%$ in $0.1 \mathrm{~N} \mathrm{HCl}$ and NLT $75 \%$ in $6.8 \mathrm{pH}$ buffer. These both formulations gave delayed release for $8 \mathrm{~h}$. FTIR characterization and DSC studies of drug with excipients indicated that there was no drugpolymer interaction. SEM photographs of tablets showed that core tablet is uniformly coated by coating layer by press coating. Stability studies showed that the formulations were stable.

\section{AUTHORS CONTRIBUTIONS}

All the author have contributed equally

\section{CONFLICT OF INTERESTS}

\section{Declared none}

\section{REFERENCES}

1. Lachman L, Liberman H, Kanig J. The theory and practice of industrial pharmacy. $3^{\text {rd }}$ ed. 2013. p. 346-73.

2. Rathore AS, Jat RC, Sharma N, Tiwari R. An overview-matrix tablet as controlled drug delivery system. Int J Res Dev Pharm Life Sci 2013;2:482-92.
3. Venkateswara RB, Navaneetha K, Rashmitha RB. Tablet coating industrial point view-a comprehension review. IJBPS 2013;3:248-61.

4. Ankit G, Ajay B, Mahesh Kumar K, Neethu K. Tablet coating techniques-concepts and recent trends. Int Res J Pharm 2012;3:50-8.

5. Kamble ND, Chaudhari PS, Oswal RJ, Kshirsagar SS, Antre RV, Wagholi P. Innovations in tablet coating technology-a review. Int J Appl Biol Pharm Technol 2011;2:214-8.

6. Winheuser J Cooper. The pharmaceutics of coating tablets by compression. J Am Pharm Assoc 1956;45:542-5.

7. Bose S, Bogner RH. Solvent less pharmaceutical coating processes: a review. Pharm Dev Technol 2007;12:115-31.

8. Rohit P, Manish J, Bhupendra SC, Sanjay KS. Compression coated tablets as drug delivery system (tablet in tablet): a review. IJPRD 2014;6:21-33.

9. Satani RR, Chotaliya MB, Raval MK, Sheth NR. Review on recent trends in press-coated pulse drug delivery system. Int Bull Drug Res 2014;4:60-91.

10. Sharma GS, Srikanth MV, Uhumwangho MU, Kumar Phani KS, Murthy Ramana KV. Recent trends in pulsatile drug delivery systems-a review. Int J Drug Delivery 2010;2:200-12.

11. Janugade BU, Patil SS, Patil SV, Lade PD. Formulation and evaluation of press coated montelukast sodium tablets for pulsatile drug delivery. IJCRGG 2009;1:690-5.

12. Sunil P, Modasiya MK, Patel VM, Patel AK. Design and development of floating pulsatile drug delivery system using meloxicam. Int J Pharm Res Bio Sci 2012;1:215-35.

13. Sonawane SJ, Chaudhari KP, Jadhao UT, Thakare VM, Tekade BW, Patil VR. Design, development and evaluation of press 
coated tablets of an antihypertensive drug. Sch Acad J Pharm 2014;3:191-6.

14. Enayatifard R, Saeedi M, Akbari J, Tabatabaee YH. Effect of Hydroxy propyl methylcellulose and ethyl cellulose content on release profile and kinetics diltiazem $\mathrm{HCl}$ from matrices. Trop J Pharm Res 2009;8:425-32.

15. Bala SK, Swain SR, Bhanja S, Sudhakar M. Formulation and evaluation of delayed release orally disintegrating tablets of lansoprazole. Indo Am J Pharm Res 2013;3:6436-59.

16. Indira MY, Jitendra KP, Sai KV, Sandeep M, Suresh Babu M, Mallikharjuna Rao P. Design and development of chronopharmaceutical drug delivery of lansoprazole. J Pharm Res 2014;8:123-9.

17. Holman LE, Leuenberger $H$. The relationship between solid fraction and mechanical properties of compacts-the percolation theory model approach. Int J Pharm 1988;46:35-44.
18. Leuenberger H, Rohera BD, Haas C. Percolation theory-a novel approach to solid dosage form design. Int J Pharm 1987;38:109-15.

19. Pham AT, Lee PI. Probing the mechanisms of drug release from hydroxy propyl methyl cellulose matrices. Pharm Res 1994:11:1379-84.

20. Skoug JW, Mikelsons MV, Vigneron CN, Stemm NL. Qualitative evaluation of the mechanism of release of matrix sustained release dosage forms by measurement of polymer release. J Controlled Release 1993;27:227-45.

21. Gangane PS, Mahajan NM, Danao KR, Pawde GN. Formulation and evaluation of chronomodulated pulsatile therapeutic system for early morning surge in blood pressure. Int J Pharm Pharm Sci 2015; 7:337-41.

22. Patel H, Pandey S, Patel V, Shah R, Tiwari S. Pulsatile release of ketoprofen from compression coated tablets using eudragit $\AA$ polymers. Int J Pharm Pharm Sci 2016;8:224-9. 